\title{
The Causes of Gender Segregation in Higher Education
}

\author{
Ruiqing Yang \\ The London School of Economics and Political Science- department of Anthropology- China in \\ comparative
}

\begin{abstract}
:
In recent years, gender segregation in the labor market has infiltrated into higher education. The sex ratios in many departments are highly unbalanced which cannot be explained by biological differences. This essay aims to explore the causes of gender segregation in the university. XJTLU is selected as the site to conduct in-depth interviews with university students. The result suggests that gender norms constructed by society and the occupational gender segregation presumably contribute to the generation of gender segregation on the university campus.
\end{abstract}

Keywords gender; segregation; higher education 


\section{Introduction}

In recent years, the ratio of women enrolling in university is increasing. In 2012, female students accounted for 51.35 percent of the total university students (Yu, 2010). Although the number of females and males is basically equal, the sex ratios in many departments are highly unbalanced. In other words, gender segregation can be observed on the university campus. To be more specific, particular subjects are more popular among students of the same sex. According to the investigation of Yu (2010) in Hunan province, 85 percent of students who majored in departments like engineering and mechanism between 1991 and 2008 are male. While another research conducted in a normal university found that male students only account for 29.36 percent of the total (Wang and Tian, 2014). This phenomenon can not be explained merely by biological reasons. Gender segregation at higher education stage is not entirely a result of individual differences in ability, endowment and effort, but a result of the interaction of various social factors, including constructed gender roles and requirements of the labor market. This essay will explore to what extent the gender norms and labor market contribute to the formation of gender segregation at the higher education stage.

\section{LITERATURE REVIEW}

The concept of gender segregation was introduced by Gross in 1968 and gradually attracted Chinese scholars' attention in recent years (Wong, 2018). Current studies mainly focus on gender segregation in the workplace. Their opinions regarding the appearance of sex segregation can be summarized into following several. A range of scholars confirmed the connection between stereotypical expectations towards gender and occupational segregation according to sex.

Firstly, the social gender division of labor significantly influences the occupational choice. Polachek (1979) and Chinese scholars Zhang and Yang (2013) discussed how family roles influence the occupation of females. They both argued that females are more likely to choose those occupations where the working time is short and flexible since they are 
expected to fulfill their family obligations, including child-bearing, housework and other caring needs.

Another group of analysts explains gender segregation from the 'demand-side.' Phelps (1972) and Arrow (1972) argued that employer usually relies on their personal belief, especially their stereotype of a group, when recruiting employees since they can never possess sufficient information of individuals. Therefore, it is very likely that employers have what Becker (1971) called a taste for discrimination and act as if recruiting male/female would reduce efficiency and increase the cost. As a result, they are unwilling to hire workers of a specific sex.

Institutional economists provide a different explanation. They attribute occupational segregation by sex to the institutional arrangement. Based on their investigation in various work organizations, Doeringer and Piore (1971) reported that women usually would encounter the hinder of the internal labor market, including limited promotion opportunities and unfair competition after entering the gendersegregated workplace. This can be illustrated by a case study offered by Jordan (1996). Jordan researched an insurance company where women have shorter job ladders and limited job training, which ensures that female employees have little space for upward mobility.

In recent years, it is noteworthy that gender segregation in the labor market has infiltrated into the field of higher education. Chinese scholars like Yu (2010) and Wang and Tian (2014) confirmed the appearance of this phenomenon in Chinese universities. However, a limited number of researches explained the causes of gender segregation in the higher education stage and this essay aims to contribute to the research of this field.

\section{$3 \quad$ Methodology}

This research relies on both in-depth interviews and literature review. According to the data collected by XJTLU, the sex ratios of industrial technology and humanities and social science faculties are highly imbalanced (see figure 1). Therefore, the author selected 21 students from departments under these two faculties to investigate reasons for sex segregation in their department. Interviewees are divided into four categories to have a comprehensive understanding of incentives of different major choices, a) 5 
female students major in the female-dominated department, b) 5 female students major in the maledominated department, c) 5 male students major in the male-dominated department, d) 6 male students major in the female-dominated department. Interviews are conducted through online voice calls or chat on Wechat and QQ. Due to the requirement of some students, their full name would not be shown in this essay.

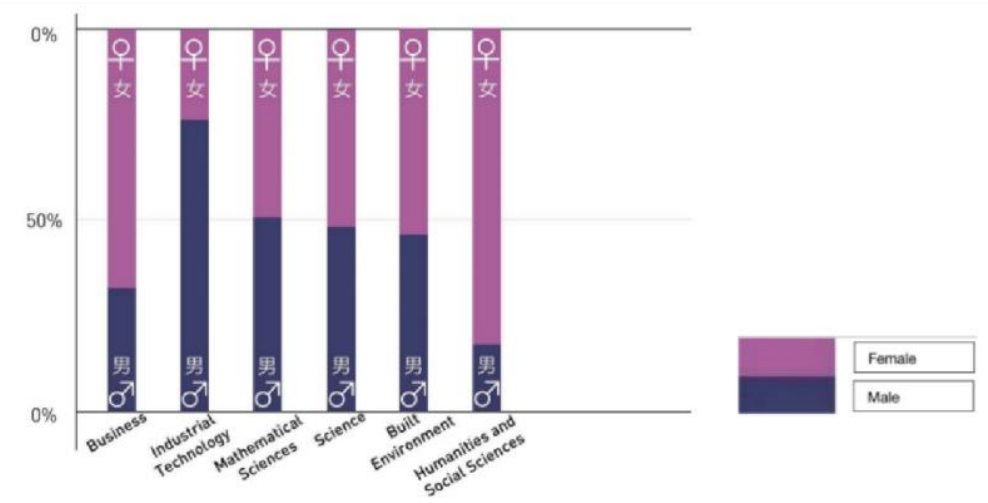

Figure 1: sex ratio of different faculties in 2018.

(https://www.xjtlu.edu.cn/en/)

\section{Discussion}

The gender stereotypes contribute to the generation of segregation. Stereotype refers to the generalization of a group. It is applied to one individual member merely because it belongs to that group. Gender stereotype generalizes attributes of men and women. It not only designates what women and men are like but also what they should be like (Kollmayer, Schober and Spiel, 2016). According to the traditional gender role, women should be gentle, sensitive and emotional. They are required to attach importance to family and try to play the role of a good wife and good mother in a family. Women who value career more than family and have to sacrifice family for personal development may be regarded as "incomplete" women, or directly referred to as "tomboy" (nan ren po) This term denies their "female" identity (Wang, 2011). Men are expected to be strong, brave, independent, rational and competitive. They should take the role of creators and pioneers. If they are indecisive, cowardly and weak, they will be regarded as "hopeless", "incompetent," or even "sissy" (Xiao, 2013). Some majors are connected 
with those gender roles. Wang (2005) introduced two concepts' male subject' and 'female subject.' The former one refers to the subject linked with masculinity and is generally considered suitable for males. While the "female subject" refers to the major, which is characterized by femininity and normally considered suitable for women. A subject connected with a stereotypical expectation of gender is more likely to attract students of one sex since society expect them to follow the gender norms. It's gendered image also prevents students of the other sex from entering it. To be more specific, if a male enters a female-dominated major, he would be considered to be lacking masculinity. Therefore, the gendered image of majors leads to gender segregation in university. One male student majors in electronic engineering and electronics department answered why his department is more attractive to male students:

I think my department is more suitable for men. We have to study for extremely long hours and most of our lessons are boring. It is a stressful department. Male students are more likely to bear hardship, but it is hard for females to deal with it. Most female students prefer departments that is less stressful.

Wang reflected the problem of being a male student in Applied English department:

Society regards English as a subject for females. Therefore, male students in this department usually considered to be 'sissy' or 'gay.' This kind of social comment prevents many male students from choosing female-dominated subjects.

Meanwhile, stereotypes towards academic performance also contribute to gender segregation. It is generally believed that women are sensitive and good at language use, but lacking mathematical ability. Men, however, are stereotyped as rational and creative and suitable for studying mathematics and physics (Li, 2009). This kind of biases shape the preference of different genders for major. In the interview, 15 out of 21 interviewees contribute the imbalanced sex ratio to the differences in the ability and endowment of gender. They agree that females are more suitable for learning liberal arts, while males have advantages in science and technology courses. As one male student, who changed his major from computer science to international relationship, reflected: 
I think most people have stereotypical thinking that males should study science and technology courses. In high school, I also had this kind of idea. Therefore, I chose computer science when I was a freshman. However, I was bad at it and failed in several modules. It was painful for me to continue to study them.

It is noteworthy that although stereotypes about academic performance can be partly supported by biological differences, a range of scholars proved that the difference in capability could not fully explain the gender segregation in education. According to the research of Feingold (1988), there is no significant statistical difference in cognitive ability between two sexes. According to a result of correlational studies, the Steinkamp and Maehr (1983) concluded that gender differences in science achievement were not large, and male's achievement in science only slightly higher than females. According to the result of Becker's (1989) research, apart from physical and biological sciences, there are no significant gender discrepancies in the achievement-test performance of other science subjects. Therefore, this kind of stereotype is a result of social ideology. The majority of interviewees also reflected that gender has little influence on academic performance in their departments.

Furthermore, gender stereotypes are maintained, strengthened and inherited through the process of 'socialization' ( $\mathrm{Li}, 2009)$. The process of gender role socialization has been started since the birth of humankind. Through the influence of family, peer, school, media and other elements, the gender role defined by society is internalized by individuals (Zhu, 2012). The 'socialization' of gender roles can be observed in the experience of some interviewees. Wang from the applied English department shared her major choosing process:

After I graduated from high school, I did not know what major I should choose. My parents suggested me to select from media, English and economy which daughters of their friends were studying. On the internet, many people recommend girls to study Chinese and English. I don't think I would be good at the economy, which has requirements for mathematics. Eventually, I chose English. In the future, I can be employed as a teacher, or translator. My parents had hoped that I could be 
a doctor or a teacher before. They believe that these two professions are stable. I agree with them.

Three female students from the male-dominated department claimed that they received negative comments from acquaintances about their major choice. One female student, one of the only three females in her department, from civil engineering complained:

After I choose this department, I have to face all kinds of queries from my relatives who know anything about my major. They believe that civil engineering is not a decent major for a girl since we usually have to go to building sites. Some also said that it is too tired and dangerous for a girl. They think girls should sit in an office with air conditions. My friends sometimes laugh about my major and calling me' brick porter.'

Additionally, the influence of the labor market should also be considered when analyzing the major choice of students since the primary purpose of receiving education for most students is finding a job. A range of explicit and implicit discrimination still exists in the labor market. In a gender-segregated industry, it is very likely for one gender to encounter entrance barriers, discrimination and limited promotion space (Xiao, 2013). For example, in some companies, male candidates would be admitted preferentially when other conditions are equal. Therefore, in the process of choosing majors, it is understandable that female students would be unwilling to invest human capital in that field. Students incline to choose majors that are friendly for their gender in the workplace to avoid unfavorable and unnecessary competition factors ( $\mathrm{Yu}, 2010$ ). Gender segregation in higher education is an explicit manifestation of occupational gender segregation. Five interviewed female students and two male students from maledominated departments believe that female students in their field would be discriminated in the labor market. On female students from the electronic engineering department claimed: 
Gender discrimination is quite common in the electronic engineering field. To be fair, it exists in most industries. But I admit that it is particularly severe in this area. Jobs related to electronics are usually tired, hard and tedious. Many companies worry that females cannot bear '996' working model (working from 9 a.m. to 9 p.m. and 6 days a week). Plus, in such an intensive and competitive field, having a child would significantly reduce of working efficiency of female employees. Therefore, companies, apart from those mega foreign ones like Google who cares about gender equality, prefer male employees.

However, it should be noticed that gender discrimination is not an element that hider male students from entering female-dominated fields. All of the interviewees from female-dominated majors believe that males would not be discriminated in their professional field. Instead, 8 of them argue that males have advantages in finding a job in female-dominated sectors. One female student from applied English department shared her experience in a translation company:

When a thing is rare, it becomes precious. During my internship in a translation company, a colleague from the human resource department reveal in a private conversation that male candidates are preferred in the recruitment. Since the firm is dominated by females, it wants to balance the sex ratio by increasing the number of male employees.

According to responses from interviewees, gender discrimination in the workplace is mainly against women. According to the gender division of labor, women are responsible for childbearing and other family responsibilities which distract them from their jobs. Therefore, for employers, female workers' career is more likely to be interrupted which will increase the cost of employment and training ( $\mathrm{Li}, 2009)$. As a result, most enterprises prefer males who are less "troublesome" under the same conditions.

The results of the interview also suggest that the social gender division of labor influence career choice and eventually major choice. Due to the influence of traditional notion that "men should be the breadwinners and women should be house carers', men 
are more likely to choose lucrative jobs than women (Wang, 2005). The results of interviews prove the argument of Xiao (2013) who believes that male students prefer science majors with strong practicality, high economic benefits and competitiveness, and tend to become high-level technical talents. Female students are more contradictory in this respect. On the one hand, they advocate the independent, strong and intelligent image of a strong modern woman, hoping to get rid of the shackles of the traditional "good wife and good mother", and have a successful career (Wang, 2005). On the other hand, they still emphasize the importance of family, because as a 'complete' woman in society, giving birth to children is still their special responsibility and mission. The conflict between professional and family roles limits the scope of employment that females could choose to some extent. They are more inclined to become management talents. Teachers, white-collar workers, civil servants and other stable and regular occupations are favored (Xiao, 2013). Stable and safe office work can achieve the expectation of both career and family. As Gong, a male student form electronics department, said:

To be honest, I chose this department partly because of its promising employment prospects. I want to find a well-paid job.

......Male usually has the responsibility to be the breadwinner of the family. Therefore, they prefer majors that allow them to find a profitable job easily. Female students do not have this kind of burden. Their parents usually only expect them to find a stable job. Therefore, it is more common for females to study liberal arts.

Liu from the media department expressed the dilemma of female:

On the one side, as a well-educated woman, I do not want to limit myself to female-dominated majors. But I think, to some extent, the existence of this phenomenon (gender segregation) is reasonable. For example, I want to have a child in the future. If most of my colleagues are male. Having a child will have a negative impact on my career and competitiveness in the company. However, in a 
female-dominated firm, reduction of efficiency caused by children would be more understandable since the majority of employees share the same experience.

The result of the existence of traditional gender roles concepts in education is that men are more likely to enter 'hard subjects' in which scientific and technological achievements can be transformed into productivity in the relatively short term. Women, on the other hand, are concentrated in 'soft subjects' like liberal art departments which is less profitable but stable or flexible (Wang, 2005).

In conclusion, interviews conducted among students in XJTLU proved that gender stereotypes contribute to the gender segregation in higher education through the process of socialization. Meanwhile, gender discrimination in the labor market and social gender roles also lead to different major choice according to gender. Gender segregation in education system channel female students into less profitable majors. This eventually would lead to the inferior economic status of female in the labor market. Therefore, it is important for universities to implement policies to encourage female enter maledominated departments. Interestingly, result shows that male students are less likely to be influenced by gender discrimination which is mainly against female workers. In the following studies, whether male and female are affected by these elements in different degree could be researched. 


\section{References}

[1] Arrow, K. A. (1973). The theory of discrimination. In O. Ashenfelter \& A. Rees (Eds.), Discrimination in Labor Markets pp. 3-33. Princeton, NJ: Princeton University Press.

[2] Becker, B. J. . (1989). Gender and science achievement: a reanalysis of studies from two meta-analyses. Journal of Research in Science Teaching, 26(2), pp.141-169. Wiley [Online]Available from:https://onlinelibrary.wiley.com/doi/abs/10.1002/tea.366 0260206 (Accessed: 8 May 2020) [3] Becker, G. S. (1957). Theory of Discrimination. Chicago: University of Chicago Press [4] Doeringer, P., \& Piore, M. . (1971). Internal labor markets and manpower analysis.

[5] Jordan, E. (1996). The ladies at the Prudential: the beginning of vertical segregation by sex in clerical work in nineteenth-century Britain. Gender and History 8(1), pp. $65-81$.

[6] Li, Y.(2009). Gender segregation in higher education and equal rights in education [高等教育性别隔离与教育平等权]. Theoretical frontier, 2009 (019), p.42-43. Cnki [Online]Available from: http://www.cnki.com.cn/Article/CJFDTOTALLLQY200919015.htm(Accessed: 8 May 2020)

[7] Li, C. (2009) Current situation and changing trend of occupational gender segregation in China[中国职业性别隔离的现状及变化

趋势 ]. Jiangsu Social Sciences, 2009(03), pp.15-22 Wanfang [Online]Available from: http://d.wanfangdata.com.cn/Periodical/jsshkx200903002 (Accessed: 8 May 2020).

[8] Kollmayer, M. Schober, B \& Spiel, C. (2016) Gender-stereotyped preferences in childhood and early adolescence: A comparison of cross-sectional and longitudinal 
data. European Journal of Developmental Psychology 16(2), PP. 198-214. Taylor $\&$ Francis

Online [Online]Available from: https://www.tandfonline.com/doi/citedby/10.1080/17405629.2016.1193483?scroll =top\&needAccess=true (Accessed: 8 May 2020)

[9] Phelps, E. (1972). The statistical theory of racism and sexism. American Economic Review 62 (4), 659-661.

[10] Polachek, S, (1979). Discontinuous labor force participation and its effect upon women's market earnings. In C. Lloyd (Ed.), Sex, Discrimination, and the Division of Labor (pp. 90-122). New York: Columbia University Press.

[11] Steinkamp, M.W. \& Maehr, M.L. (1983). Affect, ability, and science achievement: A quantitative synthesis of correlational research. Review of Educational Research, 53, pp.369-396.

[12] Wang, J. \& Tian, J. (2014). Investigation and analysis of gender differences in the selection of subjects / majors in Higher Education -- a case study of undergraduate major selection in Central China Normal University. Journal of China [高等教育 中

学科/专业选择性别差异的调查分析一以华中师范大学本科生的专业选择为案

例] Women's University 2014 (06), pp. 33-40.

Wanfang

[Online]Available

from: http://www.wanfangdata.com.cn/details/detail.do?_type=degree \&id=Y2557215(A ccessed: 8 May 2020).

[13] Wang, J. (2005) On the gender segregation of the subjects in higher education. 论高 等教育中学科专业的性别隔离 Higher education research 2005(7), pp. 56-60. Cnki [Online]Available from: http://www.cnki.com.cn/Article/CJFDTotalHIGH200507014.htm(Accessed: $\quad 8$ May 2020). 
[14] Wang, J. (2011). Shelter and reappearance: Gender Politics in academic career. Shelter and reappearance: Gender Politics in academic career. Wuhan: Central China Normal University Press

[15] Wong, Q. (2018) An analysis of the causes of gender segregation in Higher Education -- from the perspective of field theory 高 等教育中专业性别隔离的成因分析—— 以场域理论为视角 34(154) pp. 127130. Cnki [Online]Available from: http://www.cnki.com.cn/Article/CJFDTotalLZJY201801052.htm(Accessed: 8 May 2020).

[16] Xiao, B. (2013). Gender segregation in Higher Education [高等教育专业性别隔 离研究 ].Wuhan University of Engineering, Dissertation (MA) Cnki [Online]Available from:http://cdmd.cnki.com.cn/Article/CDMD-104901013359860.htm (Accessed: 8 May 2020).

[17] Yu, Y. (2010) An empirical analysis of the phenomenon of gender segregation in Higher Education: a case study of the graduates from 1991 to 2008 in Hunan Province. Heilongjiang Higher Education Research [高等教育中性别隔离现象的 实证分析——湖南省普通高校 1991 年至 2008 年毕业生为例 ], 2010(05), pp.32-34 Cnki [Online]Available from: http://www.cnki.com.cn/Article/CJFDTotal-HLJG201005009.htm(Accessed: 8 May 2020).

[18] Zhang, C \& Yang, W. (2013). Analysis on the trend and causes of occupational gender segregation in China[中国职业性别隔离趋 势与成因分析 ]. China Population Science, 2013 (02), pp.60-69. Cnki [Online]Available from: http://www.cnki.com.cn/Article/CJFDTotalZKRK201302009.htm(Accessed: 8 May 2020).

Zhu, J (2012) Gender differences in salary expectations of college students: from the perspective of gender role socialization 
$3^{\text {rd }}$ International Conference on

SOCIAL SCIENCES IN THE 21ST CENTURY

02-04 JULY, 2021

OXFORD, UNITED KINGDOM

[大学生薪水期望的性别差异:基于性别角色社会化的视角]. Women's studies, 2012 (003), pp.90-97 Cnki [Online]Available from:

http://www.cnki.com.cn/Article/CJFDTotal-FNYJ201203020.htm (Accessed: 8 May 2020) 